Anat. Labor. of Prof. H. SETO, Tohoku University, Sendai.

\title{
On the Course of Intrapontine Facial Nerve of Mammalia. I.
} 哺乳類橋内顔面神経の走行について. I.

\section{Shigeaki YAMAMOTO, Kozo TANAKA, Rikio SUGIMOTO and Yoshiya MATSUO.}

\author{
山本重亮, 田中耕三，杉本力夫 と松尾由也.
}

(Received October 22, 1955.)

As is generally known, the intrapontine facial nerve is composed of the three parts of the first part, the genu and the second part, and show a rather peculiar rnnning course, to which KAPPERS has given an interesting interpretation based on his neurobiotaxis theory.

According to this interpretation, the facial nucleus was originally situated more cranio-drosally than at present, but in the course of development, both in the phylogenetic as well as the ontogenetic meaning, it was first displaced more caudally by the stimulus from the gustatory nucleus, and then more ventrally by the stimulus from the pyramidal tract of later development. Thus, he says, the locus of transposition of the facial nucleus has plotted the course characteristic of the intrapontine facial nerve.

In 1952, YAMAMOTO made a research on the running course of the intrapontine facial nerve in human adults and ascertained that the course is not at all so simple and schematic as has been usually represented in text-books and would suit the above interpretation by KAPPERS, but is rather extremely complicated, many nerve fibres running variegated courses coming into play.

To follow up such a finding by YAMAMOTO, we undertook a comparative study of the subject nerves in many mammals of different species, as reported hereunder.

As our materials of study, we used PAL-carmine stained serial sections of brains of 20 species of mammals, namely, orang-outang and great baboon (Pitheci), lemur (Prosimii), dike. whale and dolphin (Cetacea), Bonin rosette (Chiroptera), hedgehog and musk rat (Insectivora), broadbanded armedillo, great ant-eater, two-toed sloth and long-tailed phatagin (Edentata), great kangaroo, wallaby, common native cat, Virginian opossum, thylacine, rabbit-eared bandicoot and great flying phalanger (Marsupialia) and echidna (Monotremata). 


\section{Findings.}

The course of the intrapontine facial nerve of the above mentioned animals, just as in man, generally speaking, starts from the dorsal side of the facial nucleus and running dorsocranio-medial to form the first part, goes over into the genu. In most of the animals examined, this genu is formed prior to the emergence of the abducens nucleus, but its position is different almost from animal to animal, so that some types of the relative position of the genu can be distinguished, as described hereunder. The genu takes a turn to the lateral side in the vicinity of the cranial end of the abducens nucleus, then runs ventro-caudo-laterally, to pass over into the second part of the nerve. The fibres composing the second part, while the abducens nucleus is still in view, generally pass along the dorsal side of the nucleus laterally, but some of them are seen to take different courses.

The position of the genu dorsal to the abducens nucleus is common to the different kinds of animals, but its position viewed frontally is variable, so that the three major types of central (Type I), lateral (Type II) and medial (Type III) of position relative to the abducens nucleus can be distinguished.

Type I. In a case of this type, the genu is situated just dorsal to the central one-third of the transverse section of the abducens (long-tailed

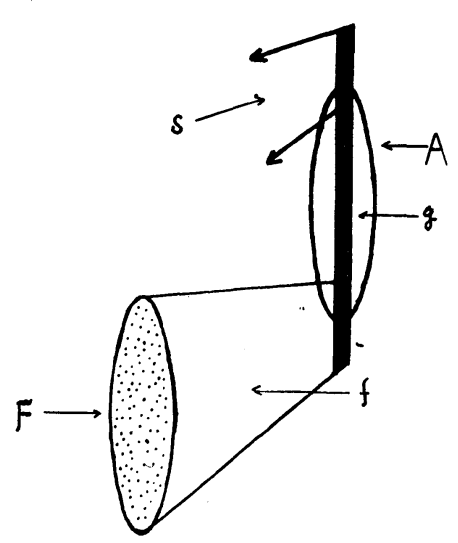

Fig. 1. Bird's-eye view of the course of the intrapontine facial nerve. $F$ facial nucleus ; $f$ first part; $g$ genu ; $s$ second part ; $A$ abducens nucleus (_ fibres running over the dorsal side of the nucleus ; ...- ditto through the nucleus ; ........ ditto along ventral side of the nucleus). phatagin). When the series of slides is examined in the order of caudalcranial direction, the genu is found formed before the emergence of the abducens nucleus into view already and the first part runs from the lateral side of the nucleus to join the genu simultaneously with the appearance of the abducens nucleus (Fig. 1).

Type II. Here, the genu is placed in the dorsal to lateral one-third of the abducens nucleus or entirely lateral to it. This type comprises two sub-types as follows:

a) The position of the genu is dorsal to the lateral one-third of the abducens nucleus (dolphin, dike whale and Virginian opossum). In this subtype, the fibres of the first part begin to form the genu before the appearance of the abducens nucleus and 
upon its appearance run along its lateral to its dorsal side to pass over into the genu (Fig. 2).

b) The genu is situated entirely lateral to the abducens nucleus (Echidna). The relative position of the genu is quite obviously different in this animal from that in any animal of other types and subtypes. In other animals, the formation of the genu is begun before the emergence of the abducens nucleus, that is on a level more caudal than the nucleus, but in the brain stem of this animal, the genu comes into formation only when the cranial end of the nucleus is approached. The fibres of the first part run dorso-craniomedial to rnn into the genu from the lateral side (Fig. 3).

Type III. This type comprises also the two subtypes of the cases where a) the genu is situated in the area dorsal to the medial one-third of the abducens nucleus and $b$ ) the genu is placed more medial entirely outside this area.

a) Thylacine, hedgehog, great kan-

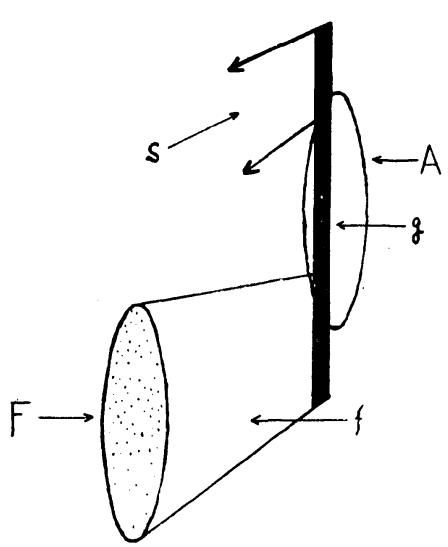

Fig. 2.

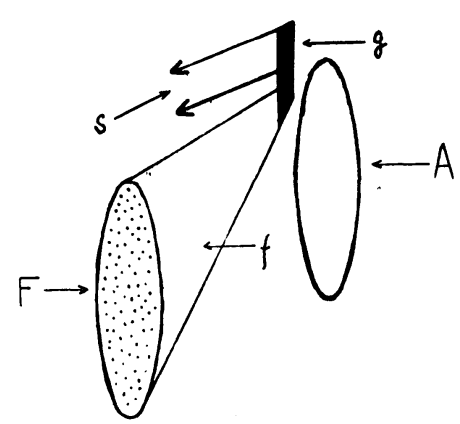

Fig. 3.

garoo, wallaby, common native cat, great ant-eater and orang outang

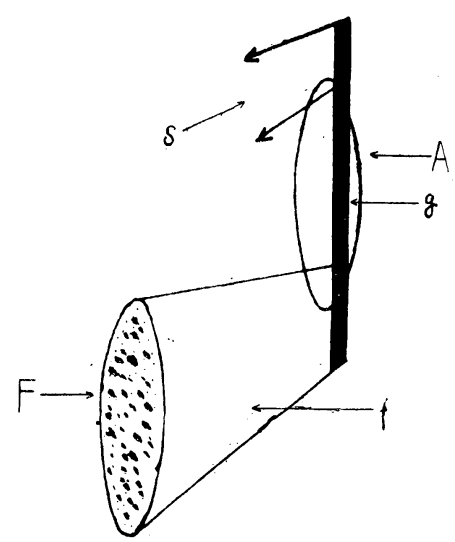

Fig. 4. belong to this subtype.

The genu of these animals is formed already before the appearance of the abducens nucleus but the course taken by the fibres of the first part before reaching the genu is not always the same, showing some difference in different animals.

1. In some, the fibres, after the appearance of the abducens nucleus, run all along the dorsal side of the nucleus into the genu (Fig. 4, thylacine).

2. In some others, the fibres, after the appearance of the abducens 


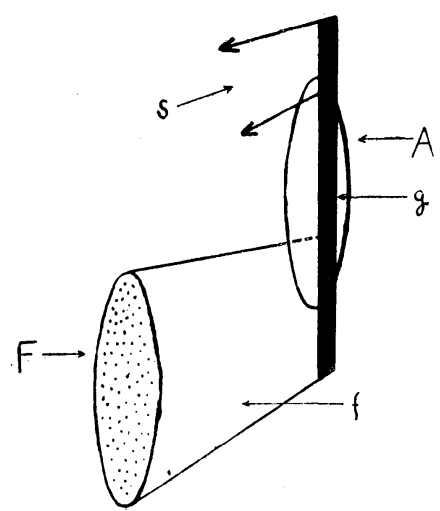

Fig. 5 .

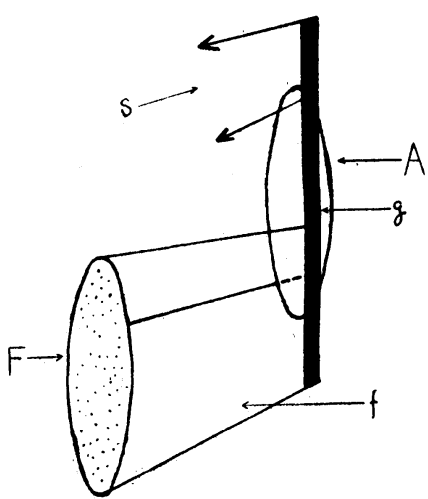

Fig. 6.

nucleus run right through it and then into the genu (Fig. 5, hedgehog, great kangaroo, wallaby, common native cat and great ant-eater).

3. In some others again, the majority of the fibres, after the appearance of the abducens nucleus, run along the dorsal side of the nucleus, but a small part of them penetrate through the nucleus, to reach the genu (Fig. 6, orang-outang).

b) In two-toed sloth, broad-banded armadillo, lemur, great baboon, Bonin rosette, musk rat, great flying phalanger and rabbit-eared bandicoot, the genu is situated entirely medial to the abducens nucleus on the dorsal side of it. The genu begins to be formed before the abducens nucleus appears on the slide, and the course of the fibres of the first and the second parts shows some variation, as follows :

1. In two-toed sloth, the fibres of the first part run always along the dorsal side of the abducens nucleus after the appearance of the latter

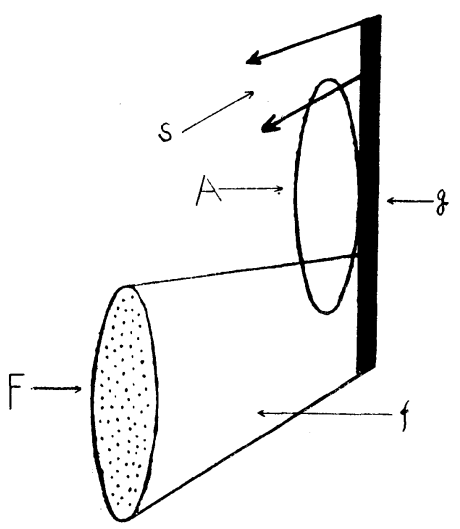

Fig. 7. (Fig. 7).

In broad-banded armadillo, the fibres of the first part take the same course, but a part of the fibres of the second part run through the abducens nucleus (Fig. 8).

2. In lemur, great baboon and Bonin rosette, the fibres of the first part run through the abducens nucleus after its appearance and reach the genu (Fig. 9).

3. In musk rat, all the fibres of the first part were found to run along the ventral side of the abducens 


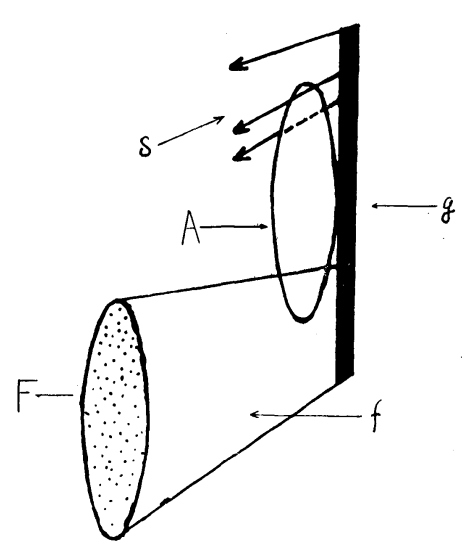

Fig. 8.

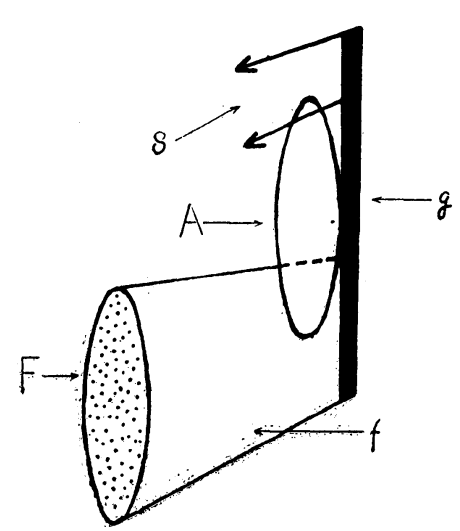

Fig. 9.

nucleus after its appearance, to reach the genu (Fig. 10).

In some other animals, the fibres of the first part took indeed the same course, but some of the fibres of the second part were seen running through the abducens nucleus (Fig. 11, great flying phalanger and rabbit-eared bandicoot).

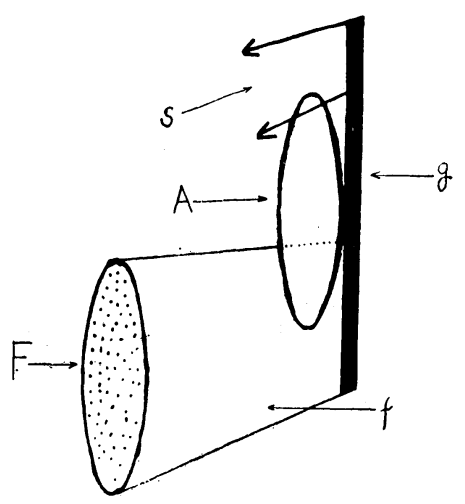

Fig. 10.

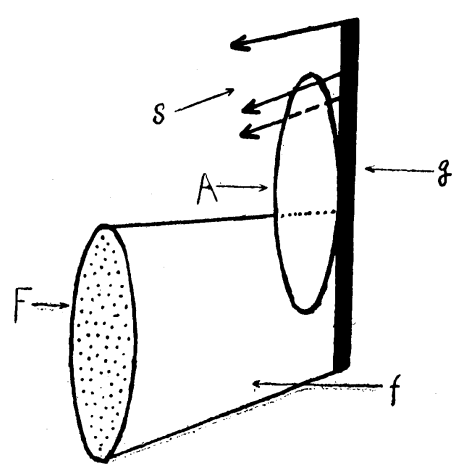

Fig. 11.

\section{Discussion.}

As described above, the intrapontine facial nerve takes varying course in different species of mammals. In particular, the position of the genu of the nerve in relation to the abducens nucleus may be classified into three types. The Type III, in which the genu is situated on the medial side of the abducens nucleus, as in man, is found to predominate, but it is of some interest that there are a considerable number of species of which the genu is placed just above (Type I) or more to 
the lateral (Type II) of the nucleus. Now, even in the animals belonging to the Types I and II, the position of the solitary nucleus is not particularly displaced toward the lateral side of the cerebral section, but is found to remain in a similar position to that in animals falling under type III, and no obvious difference is found in its morphological development between any two types, and yet, regardless of all such findings, the relative position of the genu is displaced much more to the lateral of the abducens nucleus in Types I and II. Such a variation is hard to reconcile with the interpretation in compliance with the neurobiotaxis theory of KAPPERS. Furthermore, the fact that, in spite of the rather widely varied position of the genu in Types II and III, the facial nucleus always occupies much the same position on the lateral side of the pyramidal tract at some distance from the latter, can scarcely be explained by the hypothesis of nuclear transposition effected by neurobiotaxis. We have previously studied the position of the facial nucleus in various animals and have ascertained that the position is quite similar in all of them, and have pointed out the dubious adequacy if the neurobiotaxis theory on this score, and the results of our present study tend to confirm us in our doubt.

As shown in Tab. 1, we have found to our interest that, in many cases, animals belonging to the same families showed positions of the genu belonging to different types, for example, specimens of Edentata were found in Types I and III, and Marsupialia also in Types II and III.

The genu of echidna (Monotremata) was very characteristic in that it was much shorter than the genu of all the other animals examined and was situated on the lateral side of the abducens nucleus cleanly outside of it. We have previously discovered that in the intrapontine facial nerve of birds no genu is formed, and here we have found that the nerve of echidna is nearest to that of birds in its poor formation of genu. This fact is of high interest, as is the similarity of Monotremata to birds in the formation of a cloaca, as the family name implies.

As pointed out at the outset, YAMAMOTO has studied the course of human intrapontine facial nerve and has found that it is extremely complicated, many fibres in it running in different courses. The course of the nerve in the animals examined in our study above seems to be much simpler, but here also many variable courses are taken by some nerve fibres. As shown in the preceding chapter, some of the fibres in the first as well as the second parts of the nerve contain fibres that do not always follow the main course, and in different animals, the picture is often much varied. Such a diverseness in the course of the fibres is also not easily explained by neurobiotaxis which should exert a uniform 
Table 1.

\begin{tabular}{|c|c|c|c|}
\hline Type & $\mathbf{I}$ & & Long-tailed phatagin (Edentata) \\
\hline \multirow[t]{2}{*}{ Type } & \multirow[t]{2}{*}{ II } & $\mathrm{a}$ & $\begin{array}{l}\text { Virginian opossum (Marsupialia) } \\
\text { Dike whale (Cetacea) } \\
\text { Dolhin (Cetacea) }\end{array}$ \\
\hline & & $\mathrm{b}$ & Echidna (Monotremala) \\
\hline \multirow[b]{2}{*}{ Type } & \multirow{2}{*}{ III } & a & $\begin{array}{l}\text { Thylacine (Marsupialia) } \\
\text { Great kangaroo (Marsupialia) } \\
\text { Wallaby (Marsupialia) } \\
\text { Common native cat (Marsupialia) } \\
\text { Orang-outang (Pitheci) } \\
\text { Hedgehog (Insectivora) } \\
\text { Great aut-eater (Edentata) }\end{array}$ \\
\hline & & $\mathrm{a}$ & $\begin{array}{l}\text { Two-toed sloth (Edentata) } \\
\text { Broad-banded armadillo (Edentata) } \\
\text { Musk rat (Insectivora) } \\
\text { Great baboon (Pitheci) } \\
\text { Lemur (Prosimii) } \\
\text { Bonin rosette (Chiroptera) } \\
\text { Great flying phalanger (Marsupialia) } \\
\text { Rabbit-eared bandicoot (Marsupialia) }\end{array}$ \\
\hline
\end{tabular}

traction over all the fibres.

\section{Summary.}

1. The course of the intrapontine facial nerve was studied with 20 specimens of mammalian brain stems as material.

2. The position of the genu was classified into three types in relation to the position of the abducens nucleus.

3. In 15 specimens, the relative position of the genu was similar to that in man.

4. In the 5 other animals examined, the position of the genu was displaced to right above or more to the lateral of the abducens nucleus.

5. The fibres of the first part of the nerve in some cases run right through the abducens nucleus, in some cases cover the dorsal side of the nucleus, in some other cases both the above courses are mixed in the same specimen and in other cases again, the fibres cover the ventral side of the nucleus, showing a marked diverseness of courses.

6. The fibres of the second part of the nerve penetrate through 
the said nucleus in 3 kinds of animals examined.

7. The peculiarity of the course of intrapontine facial nerve of one among the total 20 kinds studied, namely, echidna, drew our special attention.

\section{㐫 容 自 抄。}

橋内顔面神経の特有な走行を示す理由に就いては Kappers が彼の所謂 neurobiotaxis 説を以て興味ある説明をなしているが，私達は各種哺乳類 即ち猿類 (猩々, 大猅々) 擬猴類 (狐猿), 鯨類 (鮙鯨, 真海豚), 翼手類

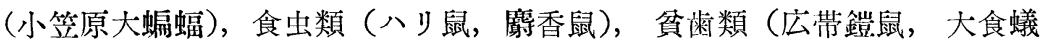
獣， 2 指樹懶，尾長穿山甲）, 有袋類（大カンガルー, ワラビイ, 袋狼, 鬼 耳袋狸, 大飛袋獣, 子守鼠, 袋イタチ) 及び単孔類（ハリモグラ）に属す る20種類の動物の橋内顔面神経の走行飞就いて観察し若干の知見を得た.

これら哺乳動物の橋内顔面神経は顔面神経核の背面より発して第 1 部, 膝及び第 2 部を形成し，膝は殆どすべての動物で外転神経核出現以前飞形 成されるが，ハリモグラだけは該核の出現後その上端近くで形成される. 外転神経核出現後の第 1 部線維の走行は動物の種類によって一様でなく, 該核を貫通するもの，外背側から包むもの，この両者を混合するもの及び 腹側から包むもの等があって複雑である．膝は外転神経核の背側飞位する ことは各種動物共飞共通であるが，その位置は該核を基準飞して，その中 央に位するもの（尾長穿山甲），その外側飞位するもの（鮙鯨，真海豚，子 守鼠，ハリモグラ）及びその内側飞位するもの（猩々，大猅々，狐猿，小 笠原大蝙蝠，八リ鼠，閯香鼠，広带鉭鼠，大食蟻獣， 2 指樹瀨，大カンガ ルー，ワラビイ，袋狼，鬼耳袋狸，大飛袋獣，袋イ夕チ）等があって，私 達は之を夫々 I 型，II型，III型として区別した。膝は外転神経核の上端あ たりで外方に方向を転じ，第 2 部に移行する，外転神経核残存中の第 2 部 は一般的には該核の背側を外方に走るが，一部分これを貫通するものも観 られる。

I 型及び II 型を示す動物の膝の位置は III 型を示す動物のそれに比して かなり外側になっているにも拘らず。これら動物の孤束核の位置は大体同 じであり，而も形態学的にはっきりした発達の差異は認められない，又II 型と III 型では滕の位置とかなりの隔りがあるとも拘らず，この両型を示 す動物の顔面神経核の位置は大体同じである。これらの事実は，第 1 部及 び第 2 部の線維走行が一様でなく，色々異った走行を示す線維を有する事 実と共飞，Kappers の neurobiotaxis 説では説明し難い所見である. 
上述せる如く哺乳動物の橋内顔面神経の走行は動物の種類によってかな りの相異を示すばかりでなく，同じ類でも相異を示し，人間のそれと比し て単純ではあるが，而も尚種々の走行を示す線維を含んでかなり複雑であ る.

\section{References.}

Kappers : Neurol. Zbl. 26(1907). S. 834. - 27 (1908). S. 958. - Ya ma moto : Tohoku J. exp. Med. 55 (1952). P. 395. - 56 (1952). P. 331. - Yamamoto, Oikawa, Konno and Ohi : Tohoku J. exp. Med. 59 (1953). P. 137. 